\title{
Comparative effects of benthic microalgae and phytoplankton on dissolved silica fluxes
}

\author{
D. E. Sigmon ${ }^{1, *}$, L. B. Cahoon ${ }^{2}$ \\ ${ }^{1}$ College of Oceanic and Atmospheric Sciences, Oregon State University, Corvallis, Oregon 97331, USA \\ ${ }^{2}$ Department of Biological Sciences, University of North Carolina-Wilmington, Wilmington, North Carolina 28403, USA
}

\begin{abstract}
Microalgal effects on dissolved silica fluxes in an estuarine sandflat were investigated over an annual cycle. Benthic microalgal and phytoplankton chlorophyll a were measured at 17 times in Masonboro Sound, NC, USA, between June 1994 and May 1995. Using light and dark benthic chambers, dissolved silica (DSi) concentrations were measured in situ and used to calculate flux rates. Mean

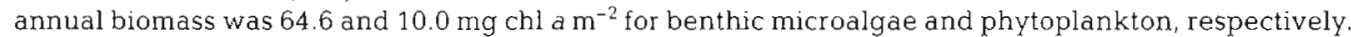
Benthic microalgae and phytoplankton (both containing diatoms), and cultured benthic diatoms were used to calculate Si:chl a weight ratios. Ratios of Si:chl a showed that benthic microalgae contain more silica per unit chlorophyll than phytoplankton, with mean Si:chl a ratios of $14.3,10.9$, and 2.8:1, for benthic microalgae, cultured benthic diatoms, and phytoplankton, respectively. DSi flux rates were always higher in the dark, while some negative flux rates (into the sediment) were seen in the light. DSi flux rates averaged $81.0 \mu \mathrm{mol} \mathrm{m} \mathrm{m}^{-2} \mathrm{~h}^{-1}$ in the dark and $37.0 \mu \mathrm{mol} \mathrm{m} \mathrm{m}^{-2} \mathrm{~h}^{-1}$ in the light. Lab and field experiments showed that benthic microalgae can take up water column DSi, while typical phytoplankton concentrations exert little control of water column DSi. Temperature was found to be the major regulator of DSi fluxes, with flux rates decreasing with decreasing temperature. Benthic microalgae were significant regulators of light chamber DSi flux at temperatures $<20^{\circ} \mathrm{C}$. Due to benthic microalgal uptake and low water column DSi concentrations observed under lower temperatures, nutrient limitation experiments were performed to determine if phytoplankton were silicate-limited. Of the 3 major nutrients, nitrogen, phosphorus, and silicon, only silicon was limiting for phytoplankton growth in every experiment. Benthic microalgae are important regulators of DSi flux, and can regulate water column DSi concentrations for at least half of the year, possibly limiting phytoplankton growth and species composition in shallow, coastal environments.
\end{abstract}

KEY WORDS: Diatoms $\cdot$ Benthic microalgae $\cdot$ Phytoplankton $\cdot$ Dissolved silica $\cdot$ Sediments $\cdot$ Flux rates

\section{INTRODUCTION}

Nutrient regeneration in the sediments is an important factor controlling the supply of nutrients to the water column (Aller \& Benninger 1981, Callender \& Hammond 1982, Flint \& Kamykowski 1984) and phytoplankton abundance in shallow water systems (Conley \& Malone 1992, Ragueneau et al. 1994). Sedimentation of biogenic particles is the primary source of regenerated material in coastal ecosystems (Hopkinson \& Wetzel 1982, Blackburn \& Henriksen 1983, Sundbäck \& Snoeijis 1991). The breakdown of these particles releases organic and inorganic forms of nutrients that

·E-mail: dsigmon@oce.orst.edu are then available for direct uptake by planktonic and benthic autotrophs (Flint \& Kamykowski 1984, Krom 1991, Sundbäck et al. 1991). Regenerated nutrients may be intercepted by benthic autotrophs, decoupling the supply of nutrients to the pelagic ecosystem (Blackburn \& Henriksen 1983, Sundbäck \& Granéli 1988, Krom 1991). In addition to nitrogen and phosphorus, silicon has also been identified as a major, possibly limiting, nutrient for microalgal growth (Officer \& Ryther 1980, Ragueneau et al. 1994).

Diffusional flux is a major process that drives nutrients out of marine sediments. Dissolved silica (DSi), in the form of silicic acid, is more concentrated in the sediments than the water column primarily due to dissolution of accumulated diatom frustules (Iler 1979, 
DeMaster 1981). Diffusional fluxes of nutrients can be altered by various factors such as turbulence, bioturbation, redox potentials, temperature, rate of sedimentation, groundwater flow, and sediment grain size (Zeitzschel 1979, Callender \& Hammond 1982, Flint \& Kamykowski 1984).

Benthic microalgae (BMA) can regulate nutrient fluxes across the sediment-water interface via direct uptake of inorganic and organic nutrients (Darley et al. 1979, Sundbäck \& Snoeijis 1991, Sundbäck et al. 1991), as well as by forming a cohesive mat over the sediment that alters chemical processes and resists mild physical forces (Kelderman et al. 1988, Sundbäck \& Jonsson 1988, Decho 1990). BMA biomass and production can be very important in coastal ecosystems (Sundbäck \& Snoeijis 1991, Cahoon \& Cooke 1992). DSi fluxes can decrease $>80 \%$ during light hours by BMA uptake (Davis 1976, Kelderman et al. 1988, Doering et al. 1989). Even in cases of enhanced nutrient release due to benthic faunal excretion and turbation, the expected fluxes out of the sediments can be masked or even reversed by BMA uptake of DSi and other nutrients (Blackburn \& Henriksen 1983, Sundbäck et al. 1991, Marinelli 1992). Therefore, a pattern of water column DSi regulation by BMA may be established in shallow, coastal ecosystems.

Diatoms are abundant benthic and planktonic photoautotrophs (Officer \& Ryther 1980, Sundbäck \& Jonsson 1988, Nilson et al. 1991), which need DSi to synthesize their solid $\left(\mathrm{SiO}_{2}\right)$ frustules (Busby \& Lewin

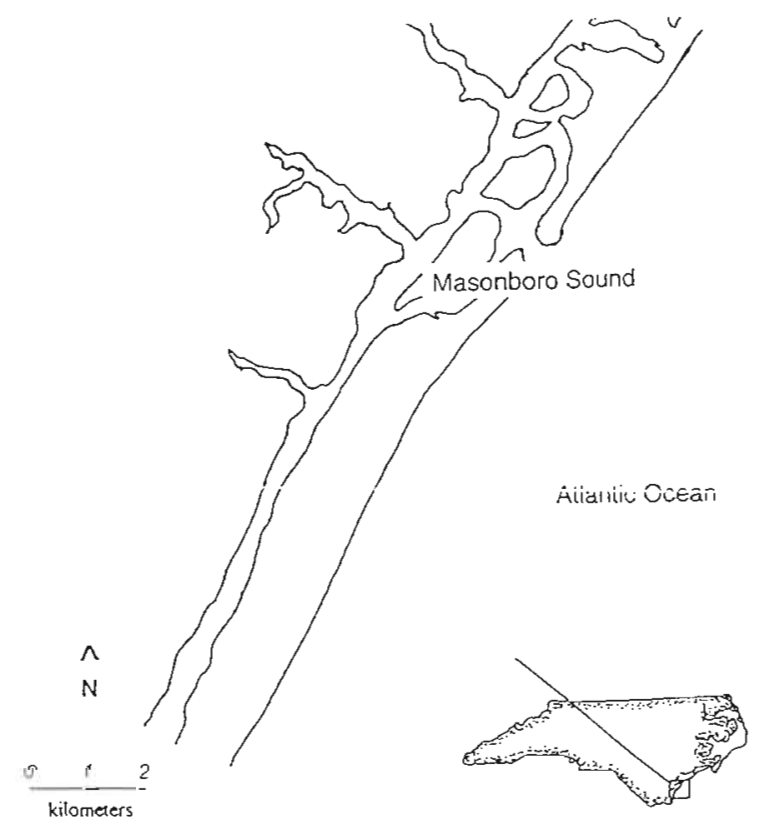

Fig. 1. Map of Masonboro Sound and adjacent area, located at approximately $34^{\circ} \mathrm{N}, 78^{\circ} \mathrm{W}$
1967, Davis 1976). Brzezinski (1985) determined that marine diatoms (all planktonic) average a nitrogen to silicon mole ratio (N:Si) of approximately 1 . Studies have also shown that diatoms have the ability to store nitrogen, but not silica, intracellularly, resulting in the need to accumulate DSi immediately prior to cell division (Busby \& Lewin 1967, Davis 1976, Doering et al. 1989). Studies of marine eutrophication with DSi indicate that diatoms can outcompete 'less desirable' cyanobacteria, and can actually lead to an increase in biomass in higher trophic levels (Doering et al. 1989, Sundbäck \& Snoeijis 1991). Because diatoms need large amounts of silica in relation to other inorganic nutrients (Davis 1976, Brzezinski 1985), DSi availability could have a significant effect on benthic and pianktonic primary production in coastal marine cnvironments, especially when other nutrients are nonlimiting (Harrison et al. 1977. Doering et al. 1989, Ragueneau et al. 1994).

The purpose of this research was to assess the influence of benthic microalgae on DSi fluxes in estuarine sediments. Seasonal variability of water column and pore water DSi concentrations and BMA DSi uptake was addressed. Relative abundance of planktonic and benthic diatoms was determined for chl $a$ and silica biomass. Nutrient limitation experiments were performed to address the possibility that phytoplankton abundance could be silica-limited due to BMA depletion of water column DSi concentrations.

\section{METHODS}

Area of study. Field research was conducted in a $33000 \mathrm{~m}^{2}$ section of Masonboro Sound, located southeast of Wilmington, NC, USA, and bordering the Atlantic Intracoastal Waterway (Fig. 1). The estuary is a marine-dominated (salinity range of 30 to $36 \mathrm{ppt}$ ), intertidal sandflat fringed by Spartina marsh and oyster beds, with a tidal range of approximately $1.5 \mathrm{~m}$ and an average water height of $0.8 \mathrm{~m}$. The sample area typically experiences minimal currents or sediment disturbance, and is connected to the Intracoastal Waterway by 2 channels. Incident radiation at the sediment surface averages $\sim 500 \mu \mathrm{E}$ during daylight hours. Seventeen subtidal locations were selected within the study area from June 1994 through May 1995. Each location was only sampled once. Sampling days were chosen to have low tide near dawn and a sufficiently low tide to deploy sampling equipment. Samples used for laboratory experiments were also collected in this area.

Sampling and analyses. Water column samples (5 replicates) were collected at all sites for DSi and chl a analysis. Water column chl a was sampled using a $50 \mathrm{ml}$ plastic syringe, and samples for DSi were col- 
lected in $10 \mathrm{ml}$ plastic syringes. Sediment samples were taken using a $2.45 \mathrm{~cm}$ diameter plastic core tube. Cores for BMA biomass analyses were collected at all sites in replicates of 6 , and cores for sediment biogenic silica (opal) and grain size analysis were collected in replicates of 5 . Five replicates of pore water samples were taken at each site using a $50 \mathrm{ml}$ syringe connected by plastic tubing to a plastic modified tip which was sealed through the middle of a petri dish, projecting $\sim 1 \mathrm{~cm}$ into the sediment, in order to eliminate intrusion of overlying water. Water column chl a was measured with a Turner 10 AU fluorometer, calibrated with pure chlorophyll (Welshmeyer 1994). Water column and pore water DSi were analyzed spectrophotometrically using the molybdenum blue method of Parsons et al. (1984). Sediment biogenic silica was determined by leaching the sediment samples in $1 \%$ $\mathrm{NaCO}_{3}$ at $85^{\circ} \mathrm{C}$ according to DeMaster (1981) and analyzed by the above method. Benthic chl a was determined by the double extraction, spectrophotometric method of Whitney \& Darley (1979), which separates intact chl a from degraded pigments. Grain size was determined by wet sieving of the sediment through 63 to $710 \mu \mathrm{m}$ mesh screens (Ingram 1971). Water column temperature data were also collected for each sample date. All water samples were analyzed within $2 \mathrm{~h}$ of the sampling time. Water and sediment surface light irradiance measurements were collected using 2 LiCor Li-193S spherical PAR (photosynthetically active radiation) sensors and an LI-1000 data-logger.

Si:chl a ratios were determined from the particulate biogenic silica leaching method and the chl a measurements for benthic and planktonic diatoms. Phytoplankton for these ratios were collected 11 times over a $7 \mathrm{wk}$ period at different tide levels in order to sample different phytoplankton communities. Benthic microalgal Si:chl a ratios were determined from the 17 sample dates. Cultured diatoms were also analyzed for chl a and biogenic silica to calculate Si:chl a weight ratios.

Flux experiments. Field experiments employed selfstirring benthic chambers as described in Cahoon \& Cooke (1992). These chambers isolated 4 l of seawater over $0.06 \mathrm{~m}^{2}$ of sediment, and were sampled at the beginning and end of a 10 to $12 \mathrm{~h}$ period for each sample date. Six light chambers, which allowed $-85 \%$ light to reach the isolated water and sediment, and 6 opaque chambers coated with black latex paint were deployed at each site. All chambers were deployed near dawn of the sampling day and removed near dusk. Visible macrofauna and flora were avoided when chambers were deployed.

All of the above described sampling protocols were performed on each sample day at the time of deployment. Initial water column and benthic samples were collected adjacent to the chambers. However, initial water column DSi samples were extracted from each chamber as well as the adjacent water on the first 7 sampling dates, but only adjacent to the chambers on the remaining dates, after finding nonsignificant differences in initial DSi concentrations between inside and outside of chambers $(t=6.34, \mathrm{df}=35$, $\mathrm{p}<0.001)$. Final samples were collected from each chamber for water column chl a and DSi just prior to chamber retrieval.

Laboratory uptake experiments. Laboratory manipulations of a simulated in situ community used sediment and water column samples collected from 2 different locations in Masonboro Sound. Circular containers measuring $6 \mathrm{~cm}$ in diameter and $14 \mathrm{~cm}$ high were used to grow and manipulate the collected benthic and planktonic microaigae. The containers, each of which contained sediment and water, were placed in a $21^{\circ} \mathrm{C}$ lighted incubator $(-300 \mu \mathrm{E})$ for $24 \mathrm{~h}$. Air pumps were used to continuously circulate the water in each container. Three different treatments were used for each experimental period: (1) sediment and seawater with microalgae; (2) sediment with microalgae and filtered seawater (no phytoplankton); and (3) clean sand (no microalgae) with filtered seawater as the control. Approximately $400 \mathrm{ml}$ of the appropriate water was used in each container. Five replicates were used for the first 2 treatments, and 4 replicates were used for the control.

DSi was added to each container to $\sim 20 \mu \mathrm{M}$. Samples $(5 \mathrm{ml})$ were collected from each container prior to, immediately following, and at 3, 6, 12 and $24 \mathrm{~h}$ after Si addition for DSi analysis. In addition to those collected for the experiments, water column and benthic samples were also collected for initial chl a measurements, as previously described. After the $24 \mathrm{~h}$ period, sediment and water from the first 2 treatments were also sampled and measured for water column and benthic chl a.

For comparison to the Si:chl a ratios of natural assemblages of benthic and planktonic microalgae, a ratio for cultured diatoms was also calculated. Five individual species and 1 mixed assemblage of attached diatom species were cultured in a modified $\mathrm{f} / 2$ nutrient solution with DSi (Guillard \& Ryther 1962). These cultures were used to calculate Si:chl a ratios of cultured benthic diatoms using the fluorometric method for chl a analysis. After drying these samples (to remove the acetone), biogenic silica content was determined by dissolving the silica in basic solution and analyzing spectrophotometrically, as previously described.

Nutrient enrichment experiments, including the use of nitrogen, phosphorus, and silicon, were conducted to determine if phytoplankton growth was silicalimited. Seawater samples from Masonboro Sound were collected on 3 consecutive weeks during Febru- 


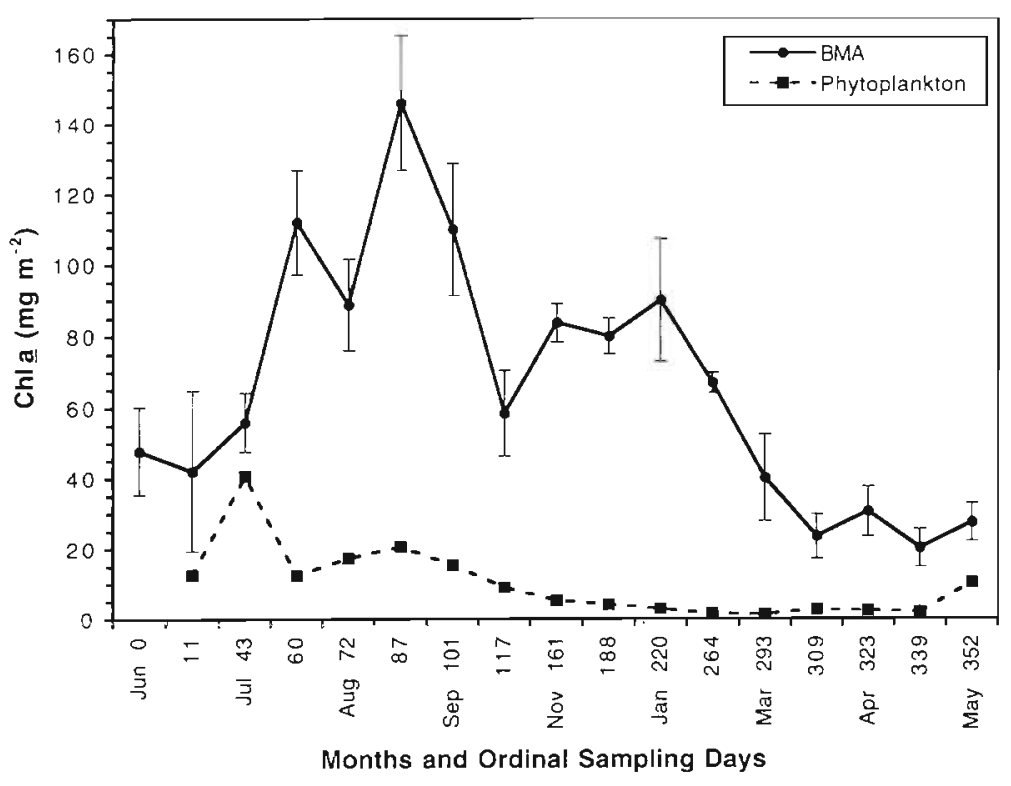

Fig. 2. Benthic microalgal (BMA) and phytoplankton biomass from 2 June 1994 through 20 May 1995 (error bars = 1 SD)

ary 1996, when water column DSi concentrations were shown to be low, and incubated in a greenhouse for $5 \mathrm{~d}$. Initial samples and 5 replicate samples for each nutrient addition treatment were collected in 11 plastic cube containers. Four nutrient treatments were used in the first 2 experiments: $+\mathrm{Si},+\mathrm{N}+\mathrm{Si},+\mathrm{P}+\mathrm{Si}$, and the control (no nutrients). The third experiment also used 4 treatments: $+\mathrm{Si}_{1}+\mathrm{P}_{1}+\mathrm{P}+\mathrm{Si}$, and the control. All samples given nutrients were also given modified $\mathrm{f} / 2$ vitamins and trace metals. A $1 \mathrm{ml}$ volume of the appropriate nutrient(s) was added to the containers on all 5 days, and the samples were mixed after each addition. $\mathrm{Chl}$ a was measured fluorometrically for initial samples and for each sample at the end of each experiment in order to determine changes in biomass.

\section{RESULTS}

\section{Field measurements}

Bcnthic chl a was always greater than phytoplankton chl a throughout the study period (Fig. 2). Biomass measurements showed a BMA mean of 64.6 ( $\mathrm{SE}=8.8$ ) $\mathrm{mg}$ chl a $\mathrm{m}^{-2}$ with a peak of 145.6 in late August 1994, while mean phytoplankton biomass was 10.0 ( $\mathrm{SE}=2.5$ ) $\mathrm{mg}$ chl a $\mathrm{m}^{-2}$ and reached its peak chl $a$ of $40.7 \mathrm{mg} \mathrm{m}^{-2}$ in mid-July 1994. The mean biomasses of the 2 algal assemblages were significantly different $(t=5.81, \mathrm{df}=$ $15, \mathrm{p}<0.001)$. In general phytoplankton were more abundant from late spring to early summer, while BMA were more abundant from late summer to mid-winter.
Phytoplankton biomass always decreased in both light and dark chambers. At all sites, the final phytoplankton concentrations were below $10 \mu \mathrm{g}$ chl a $\mathrm{l}^{-1}$ or $1.7 \mathrm{mg}$ $\mathrm{m}^{-2}$, even during the bloom period. Therefore, phytoplankton never comprised more than $5 \%$ of total chl $a$ in the chambers at the end of each experiment.

Water column and pore water DSi were highest in late summer and lowest in late winter/early spring (Fig. 3). Water column concentrations were always lower than pore water concentrations, and never greater than $15 \mu \mathrm{M}$. Pore water DSi concentration reached a peak of $94.7 \mu \mathrm{M}$ in mid-August 1994. Sediment biogenic silica (BSi) displayed the same trend as BMA biomass and pore water DSi concentrations, with highest values in late summer and decreasing values in late winter. BSi content ranged from $0.0068 \%$ by weight of sediment in August 1994 to $0.0012 \%$ in May 1995, and averaged $0.0035 \%$ (SD = $0.0017 \%$ ) over the entire year (Fig. 3).

Si:chl a ratios were derived from previously measured values of BSi and chl $a$, for both benthic and planktonic samples that contained diatoms and other algal types. Sediment microalgae averaged a Si:chl a ratio of 14.3 to $1(\mathrm{SD}=3.3$ ) and cultured benthic diatom species averaged 10.9 to $1(\mathrm{SD}=1.6)$. Phytoplankton averaged a Si:chl a ratio of only 2.8 to $1(\mathrm{SD}=1.6)$. The ratios for benthic and planktonic microalgae were significantly different ( $t=10.2, \mathrm{df}=31, \mathrm{p}<0.001$ ), as were the ratios for cultured benthic diatoms to phytoplankton $(t=9.4, \mathrm{df}=15, \mathrm{p}<0.001)$, indicating that benthic diatoms have a significantly greater proportion of silica than phytoplankton. Using the corresponding Si:chl a ratios, average biomasses were converted to 924 and $28 \mathrm{mg} \mathrm{m}^{-2}$ of silica for BMA and phytoplankton, respectively. Mean BMA silica biomass was greater than 33 times phytoplankton silica biomass.

Grain size data revealed that the sediment at all sites was composed primarily of various sized sands, with $<1.5 \%$ silts and clays. The major size fraction was fine sand (0) 125 to $0.250 \mathrm{~mm}$ diameter). comprising $>49 \%$ of sediments at all sites. Water temperature in the study area was $>25^{\circ} \mathrm{C}$ from June to September, decreased through winter, and began to increase in March 1996. Maximum water temperature of $30^{\circ} \mathrm{C}$ was reached in August, corresponding to the peak in water column and pore water DSi concentrations, and sediment BSi content. The minimum temperature of $9^{\circ} \mathrm{C}$ was in February and corresponded to the lowest pore water DSi concentration. Light measurements were collected on 7 of the 17 sample days and showed an 


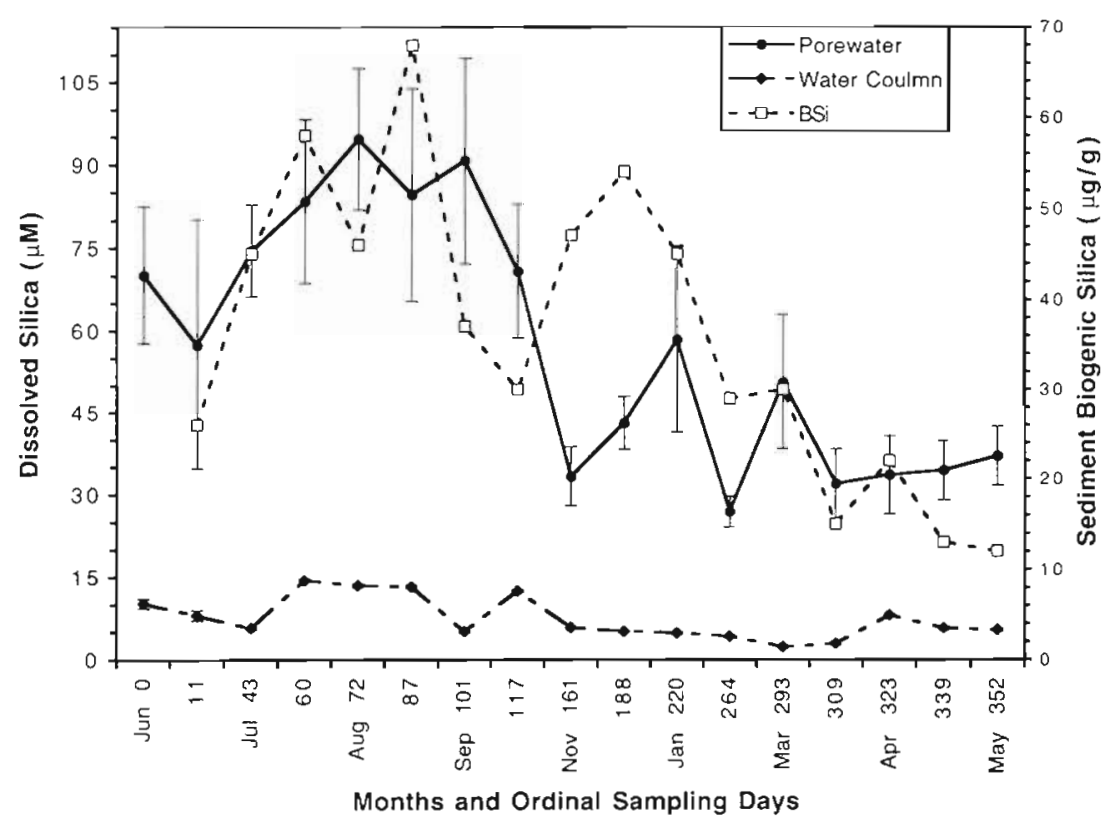

Fig. 3. Pore water and water column dissolved silica concentrations, and sediment biogenic silica (BSi) content from 2 June 1994 through 20 May 1995 (error bars = 1 SD)

$\mathrm{yr}^{-1}$ in the light. Assuming that the actual yearly DSi flux would be the average of the light and dark flux calculations, this area of Masonboro Sound releases $517 \mathrm{mmol}$ DSi $\mathrm{m}^{-2}$ annually.

Pearson's correlation analyses indicated that 4 parameters were significantly associated with either light chamber or dark chamber DSi flux: BMA biomass, pore water DSi concentration, water temperature, and sediment grain size (Table 1). A regression of DSi flux versus temperature showed that there were 2 significantly different data sets for DSi fluxes, one for temperatures equal to or greater than $23^{\circ} \mathrm{C}$, and the other for temperatures less than or equal to $20^{\circ} \mathrm{C}(t=6.35, \mathrm{df}=32, \mathrm{p}<$ 0.001 ), making temperature a significant controlling factor of both light and dark chamber fluxes (Fig. 5). Therefore, a multiple linear

average sediment surface light flux of 517 ( $\mathrm{SD}=230$ ) $\mu \mathrm{E}$, ranging from 169 to $885 \mu \mathrm{E}$. Sea surface mean irradiance was $1650 \mu \mathrm{E}$ and ranged from 685 to $2120 \mu \mathrm{E}$, with surface and benthic minima and maxima occurring in February and May 1995, respectively. regression (MLR) analysis using SAS 6.0 was performed on light and dark chamber DSi fluxes, with temperature data converted into 2 categories (high and low), instead of numerical data.

MLR models of dark chamber DSi fluxes showed that temperature and pore water concentration had a significant effect on flux $(F=30.79, \mathrm{df}=15, \mathrm{p}<0.001)$ with an

\section{Flux data}

Nutrient flux measurements showed that light chambers had lower fluxes of DSi out of the sediment than dark chambers at every site (Fig. 4). Average fluxes of DSi were $81.0 \mu \mathrm{mol} \mathrm{m}{ }^{-2} \mathrm{~h}^{-1}(\mathrm{SE}=13.4)$ for dark chambers and $37.0 \mu \mathrm{mol} \mathrm{m}{ }^{-2} \mathrm{~h}^{-1}(\mathrm{SE}=10.5)$ for light. Mean light chamber DSi flux was significantly less than that in the dark ( $t=$ $2.6, \mathrm{df}=32, \mathrm{p}<0.01$, and only the second sample site displayed a non-significant difference. Rates for DSi flux ranged from 11.0 to $190.3 \mu \mathrm{mol} \mathrm{m}{ }^{-2} \mathrm{~h}^{-1}$ for dark chambers and -22.3 to 115.9 for light chambers. Four of the sample dates (November to February) displayed negative net flux rates into the sediments, and on 5 dates (November to March) DSi concentration was maintained at or decreased below $4 \mu \mathrm{M}$ at the end of each sample day. Averaged over the entire year, DSi flux would be $1.95 \mathrm{mmol}$ $\mathrm{m}^{-2} \mathrm{~d}^{-1}$ or $710 \mathrm{mmol} \mathrm{m}^{-2} \mathrm{yr}^{-1}$ in the dark and $0.89 \mathrm{mmol} \mathrm{m}^{-2} \mathrm{~d}^{-1}$ or $324 \mathrm{mmol} \mathrm{m}^{-2}$

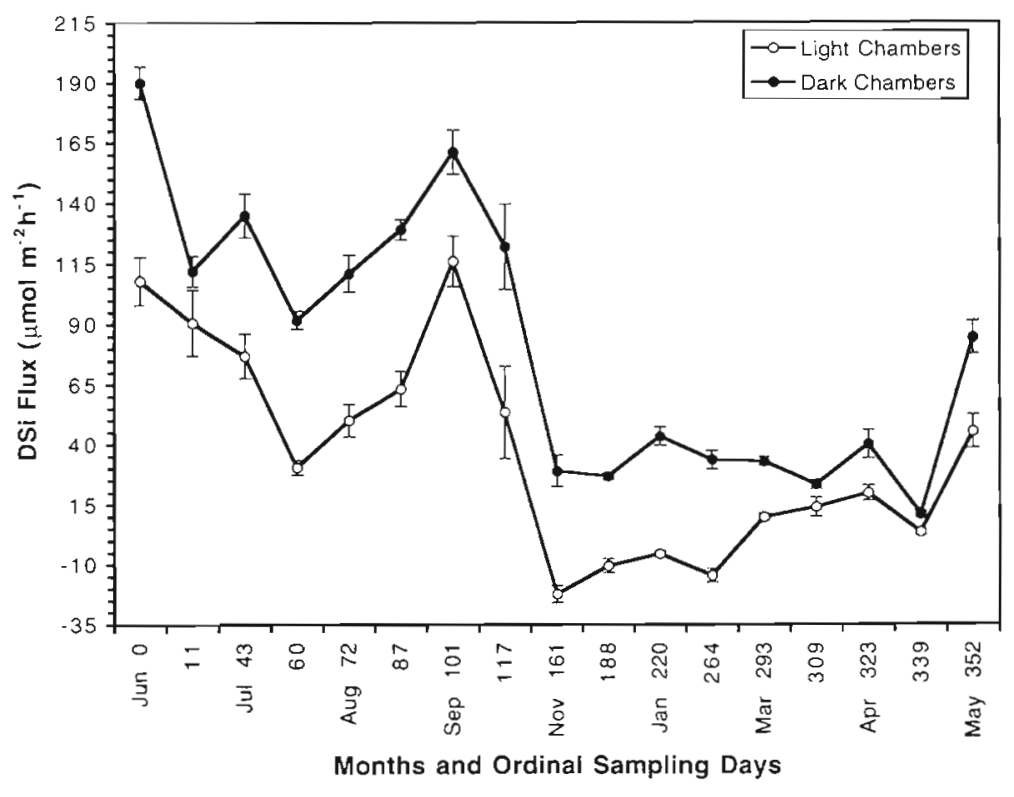

Fig. 4. Rates of dissolved silica (DSi) fluxes out of sediment in light and dark chambers from 2 June 1994 through 20 May 1995 (error bars = 1 SE) 
Table 1. Pearson's correlation analyses for field measurements (r-values are given; $p<0.05, \cdots p<0.01$; df $=15$ ). LC: light chamber; DC: dark chamber

\begin{tabular}{|c|c|c|c|c|c|c|c|}
\hline & Temp & $\mathrm{BMA}$ & Pore water & Grain size & $\mathrm{BSi}$ & LC flux & DC flux \\
\hline Temp & - & 0.21 & $0.74 \cdots$ & 0.27 & 0.23 & $0.76^{\circ}$ & $0.79 \cdots$ \\
\hline $\mathrm{BMA}$ & & - & $0.64^{\cdots}$ & $-0.55^{\circ}$ & $0.88^{*}$ & $-0.82^{\cdots}$ & -0.17 \\
\hline Pore water & & & - & $-0.59^{\circ}$ & $0.55^{\bullet}$ & $0.69 \cdots$ & $0.79 \cdots$ \\
\hline Grain size & & & & - & -0.32 & -0.44 & $-0.56^{\circ}$ \\
\hline $\mathrm{BSi}$ & & & & & - & 0.29 & 0.19 \\
\hline
\end{tabular}

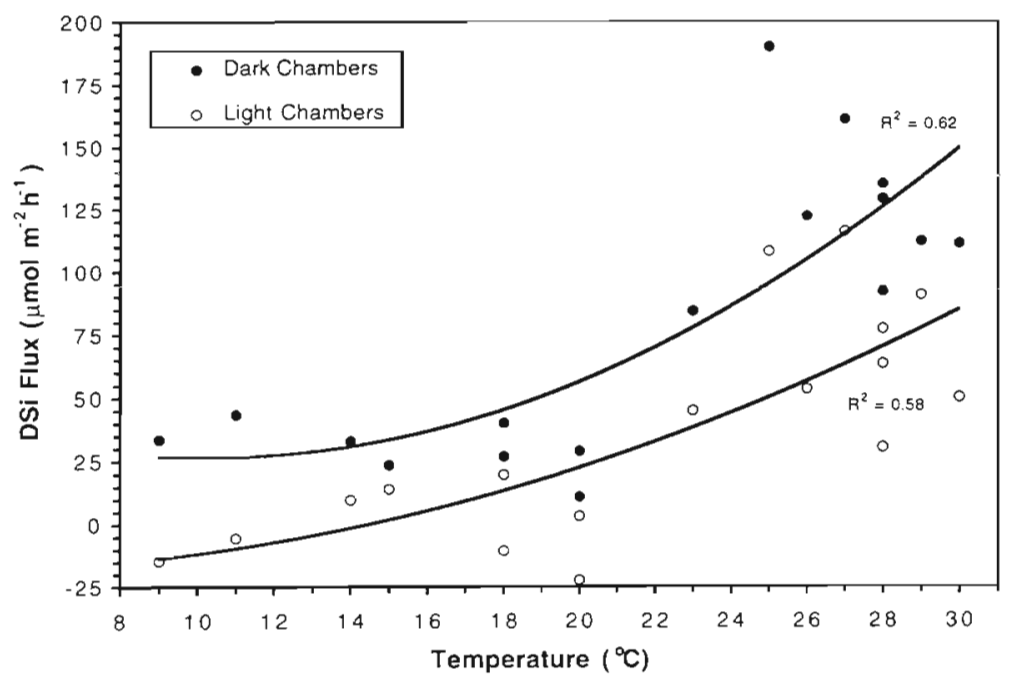

Fig. 5. Regression of DSi fluxes in light and dark chambers as a function of temperature
BMA, but not in the control group, indicating direct uptake by BMA. The DSi decreases in the 2 microalgal treatments (with and without phytoplankton) were not significantly different trom each other $(p<$ 0.05) (Fig. 6). Significant decreases of DSi were observed at $12(t=4.35, \mathrm{df}=16, \mathrm{p}<$ $0.001)$ and $24 \mathrm{~h}(t=8.07, \mathrm{df}=16, \mathrm{p}<0.001)$ in both experiments (Table 2). DSi flux calculations showed that both BMA treatments averaged uptake rates greater than 60 and $45 \mu \mathrm{mol} \mathrm{m} \mathrm{m}^{-2} \mathrm{~h}^{-1}$ for the first and second experiment, respectively (Table 2). Control treatments decreased slightly over the $24 \mathrm{~h}$ experiment period. An ANOVA model showed a significant effect of BMA on DSi flux $(F=33.12, \mathrm{df}=27, \mathrm{p}<0.001)$. It also showed treatments with BMA sedi- $r^{2}=0.90$. Therefore, dark chamber fluxes were regulated by simple diffusion, which is a function of the concentration gradient and temperature. Temperature alone accounted for $86 \%$ of the variability in dark chamber DSi flux data $(F=25.78, \mathrm{df}=15)$. For light chamber fluxes temperature, pore water concentration, and BMA biomass were each significant factors at the 0.05 level $\left(F=28.53, \mathrm{df}=15, \mathrm{p}<0.001 ; \mathrm{r}^{2}=0.85\right)$. Therefore, BMA were able to modify diffusive DSi flux under lower temperatures. Temperature accounted for $72 \%$ of variability in light chamber DSi fluxes $(F=13.52, \mathrm{df}=$ $15, p<0.001$ ) and was the major factor driving sediment DSi fluxes. Pore water DSi concentration was also strongly, positivcly corrclated $(p<0.01)$ with temperature, indicating that temperature may influence DSi concentrations. BMA biomass was positively correlated with pore water DSi concentration and sediment biogenic silica $(\mathrm{df}=15, \mathrm{p}<0.05)($ Table 1$)$.

\section{Dissolved silica uptake experiments}

The replicate experiments showed that water column DSi decreased in both treatments containing
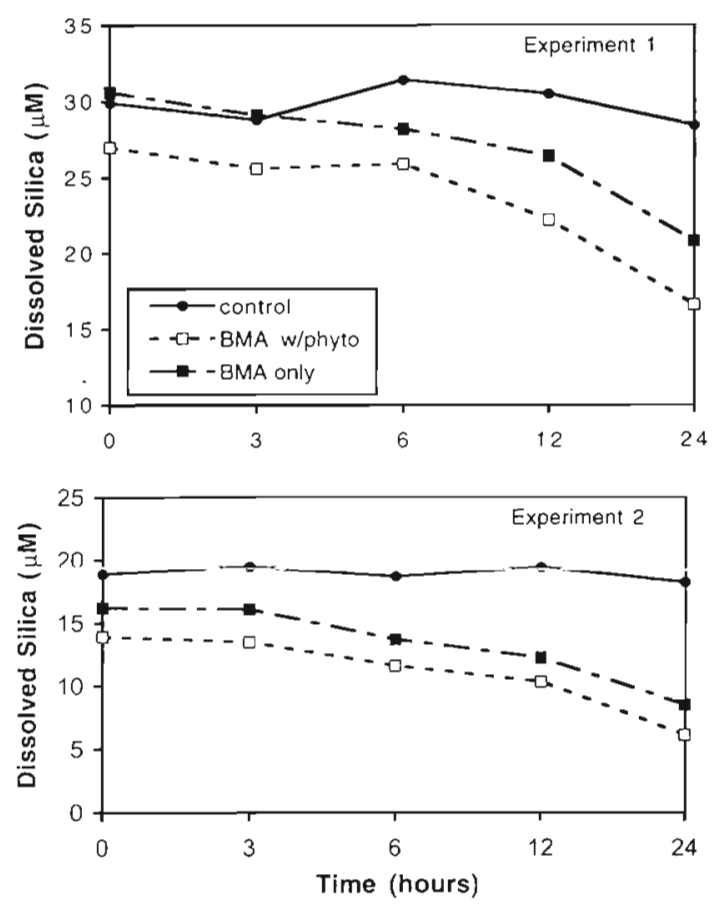

Fig. 6. Change in water column DSi concentrations over time (SD $<3 \mu \mathrm{M}$ for all treatments and times) 
Table 2. Change in mean water column dissolved silica concentrations $(\mu \mathrm{M})$ and flux rates ( $\left.\mu \mathrm{mol}^{-2} \mathrm{~h}^{-1}\right)$ (standard errors in parentheses)

\begin{tabular}{|c|c|c|c|c|}
\hline Expt/Treatment & $6 \mathrm{~h}$ & $12 \mathrm{~h}$ & $24 \mathrm{~h}$ & Flux rate \\
\hline 1. BMA + phytoplankton & $-1.2(0.5)$ & $-4.8(1.1)$ & $-10.4(1.9)$ & $-61.9(11.4)$ \\
\hline BMA only & $-1.8(1.0)$ & $-4.2(0.1)$ & $-10.3(0.8)$ & $-61.3(4.8)$ \\
\hline Control & $1.5(1.1)$ & $0.6(0.7)$ & $-1.6(0.1)$ & $-9.5(5.1)$ \\
\hline 2. BMA + phytoplankton & $-2.3(0.3)$ & $-3.6(0.4)$ & $-7.8(0.2)$ & $-46.4(1.3)$ \\
\hline BMA only & $-2.5(0.4)$ & $-4.0(0.6)$ & $-7.7(0.8)$ & $-45.8(4.5)$ \\
\hline Control & $-0.2(0.6)$ & $0.5(0.5)$ & $-0.5(0.3)$ & $-3.0(1.5)$ \\
\hline
\end{tabular}

ment cores had significantly greater DSi uptake rates than the control $(t=3.52, \mathrm{df}=25, \mathrm{p}<0.02)$.

BMA biomass did not significantly change over the $24 \mathrm{~h}$ period in either treatment for either experiment. Initial BMA biomass was 28.1 (SE = 3.0) and 22.1 (SE $=1.2 \mathrm{l} \mathrm{mg} \mathrm{chl} a \mathrm{~m}^{-2}$ in the first and second experiment, respectively. Initial phytoplankton biomass was 1.7 $(\mathrm{SE}=0.1)$ and $0.4(\mathrm{SE}=0.1) \mathrm{mg} \mathrm{chl} \mathrm{a} \mathrm{\textrm {m } ^ { - 2 }}$ in the first and second experiment, respectively. Phytoplankton biomass decreased to $<0.25 \mathrm{mg}$ chl a $\mathrm{m}^{-2}$ in both replicate experiments and comprised less than $6 \%$ of total chl a biomass at the beginning of each experiment and less than $1 \%$ at the end of the experiments. Therefore, nearly all of the DSi uptake can be attributed to BMA.

The nutrient limitation experiments showed that only DSi was a limiting nutrient for phytoplankton growth in all 3 experiments, and that the +P+Si treatment supported the highest phytoplankton growth (Fig. 7). ANOVA models of all 3 nutrient experiments revealed that there were significant differences between the nutrient treatments on phytoplankton growth $(F>$ $12.5, \mathrm{df}=19, \mathrm{p}<0.0001$ for all). StudentNewman-Keuls tests were performed for each experiment to determine which treatments supported the highest phytoplankton growth. In the first experiment, all treatments were different from each other and the $+\mathrm{P}+\mathrm{Si}$ treatment produced the highest phytoplankton growth. In the second experiment only the $+\mathrm{P}+\mathrm{Si}$ treatment, which produced the highest growth, was different from the others. A SNK test on the third experiment revealed that $+\mathrm{P}+\mathrm{Si}$ and + Si treatments resulted in phytoplankton growth that was statistically higher than the other treatments. Unlike DSi and phosphorus, treatments with nitrogen did not stimulate phytoplankton growth.

\section{DISCUSSION}

BMA biomass was always higher than phytoplankton values throughout the study period. The difference in microalgal concentrations on each of the 17 sampling dates revealed that BMA chl a averaged more than 10 times that of phytoplankton. BMA are therefore the major components of annual primary producers in the Masonboro Sound sand flat area, due to the visible absence of macroalgae except between February and March 1995 and to the low annual biomass of phytoplankton. This finding supports other results from studies in soft-bottom, coastal areas (Lukatelich \& McComb 1986, Sundbäck \& Jonsson 1988).

Ratios of Si:chl a from field and laboratory samples show that benthic diatoms contain and require significantly more silica per unit of chlorophyll than do planktonic forms. This result is expected when considering that lighter planktonic cells will sink much more slowly than the dense, Si-rich frustules of benthic

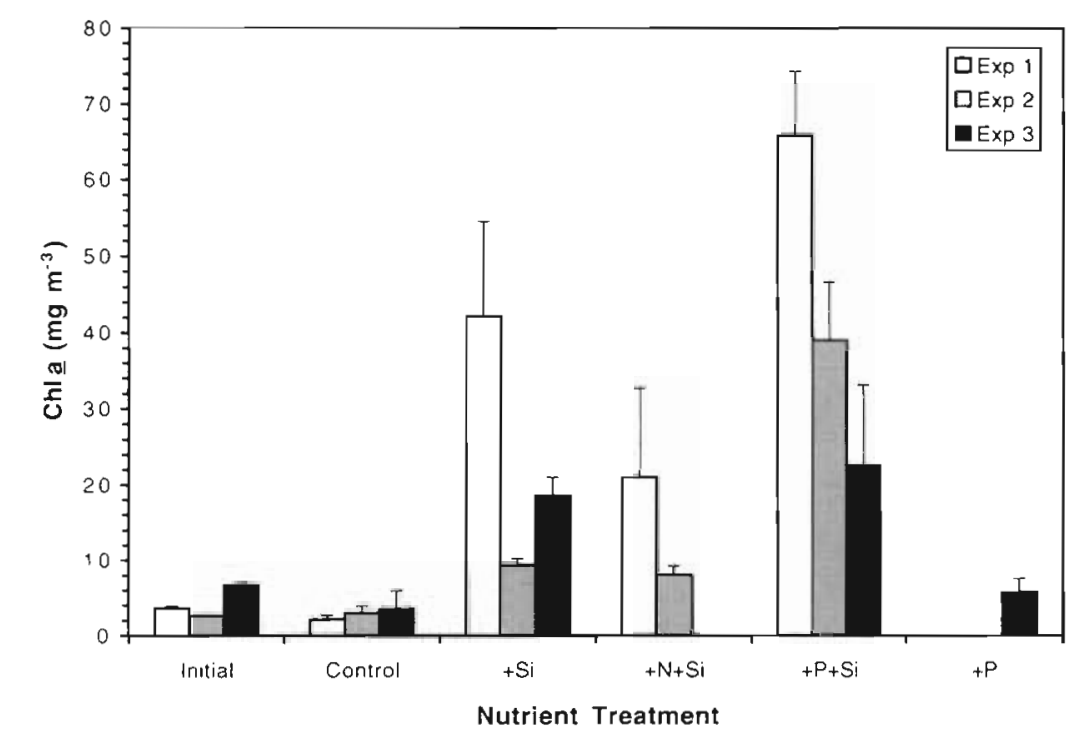

Fig. 7. Phytoplankton biomass after $5 \mathrm{~d}$ incubation under different nutrient treatments (error bars $=1 \mathrm{SD}$ ) 
diatoms. The average Sichl a ratio of cultured benthic diatoms was lower than the field BMA ratio, probably resulting from the accumulation of biogenic silica, but not chlorophyll, in cells buried deeper within the sediment. Therefore, benthic diatoms can be an important source of and sink for silica in shallow water marine environments. Both field and laboratory experiments show that with low turbulence, phytoplankton will either sink out of the water column or attach to the experimental chamber.

Laboratory results support the conclusions that BMA are the dominant sink for silica and can control DSi flux rates in the Masonboro sand flat. When BMA, and not their planktonic counterparts, are abundant, they can greatly modify or even stop the net flux of DSi out of shallow water marine sediments. The average flux of DSi from the sediments is $106.4 \mathrm{mg} \mathrm{m}^{-2} \mathrm{~d}^{-1} \mathrm{com}-$ pared to annual phytoplankton silica standing stock of $28 \mathrm{mg} \mathrm{m}^{-2}$, which means that the amount of silica being supplied to the water column per day is about 4 times the amount of silica sequestered in planktonic diatoms. This result suggests that on an annual basis DSi is not limiting for phytoplankton and that BMA are not regulating phytoplankton productivity. However, when the effect of temperature is considered, the average flux rate of DSi for temperatures of $<20^{\circ} \mathrm{C}$ is $25.4 \mathrm{mg} \mathrm{m}^{-2} \mathrm{~d}^{-1}$. This average flux rate, calculated over a $178 \mathrm{~d}$ sampling period from November 1994 to April 1995, shows the amount of DSi that is being recycled on a daily basis is less than the average daily phytoplankton silica biomass of $28 \mathrm{mg} \mathrm{m} \mathrm{m}^{-2}$. Therefore, for half of the year, silica may be a limiting nutrient for phytoplankton growth, due to BMA uptake and control of water column DSi. Nutrient addition experiments revealed that DSi was the major limiting nutrient for phytoplankton growth for the month of February when water column DSi concentrations and temperature are low, and that phosphorus, not nitrogen, became secondarily limiting when DSi was abundant.

Flux rates are influenced by several factors depending on the time of year and the availability of light. Water temperature is the controlling physical factor on an annual basis, due to the lowered solubility and dissolution of biogenic silica at lower temperatures. According to Iler (1979), with a $20^{\circ} \mathrm{C}$ drop in tompora ture, biogenic silica solubility decreases by $44 \%$ and dissolution rates decrease by a factor of $>10$. The presented results indicate that the diffusional flux at higher temperatures, created by rapid silica dissolution within the sediments and the corresponding high pore water concentrations, is too high for benthic diatoms to regulate the flux of DSi out of the sediments. However, at lower temperatures, the dissolution rate slows and pore water values decrease, allowing BMA to modify the diffusional flux of DSi and in some instances reverse the normal flux out of the sediment. This process is further enhanced by the decrease in the diffusion rate of DSi with decreasing temperature, effectively decreasing the rate at which DSi could be leaving the sediments. Therefore, at higher temperatures, BMA uptake is minor compared to the high flux rate of DSi out of the sediments, but when water temperatures fall below $20^{\circ} \mathrm{C}$, the impact of BMA on DSi fluxes becomes proportionately greater than dissolution and diffusion, creating negative flux values.

Light is the controlling factor on a diurnal basis, as supported by the differences in fluxes at different tem. peratures and between light and dark conditions. Therefore, BMA DSi uptake is light-driven, supporting previous findings on diatom silica uptake (Davis 1976). In addition, all of the chamber experiments were conducted on days when the average height of water covering the sediment was highest and, therefore, light was lowest. With low tides being at dawn and dusk, and high tide at mid-day, average daily light reaching the sediment would be lower than on days with a mid-day low tide. Therefore, the differences between light and dark fluxes were probably underestimated, especially on an annual basis. The primary production of BMA could also aid in the aeration of the sediment surface, resulting in the increased dissolution of particulate silica under more oxidizing conditions. Increased dissolution can result from the enhanced decomposition of organic material surrounding the frustules in aerobic conditions (Vandevivere et al. 1994) and the oxidation of complexed metals (Iler 1979). This is a possible explanation for the positive correlation between pore water DSi concentrations and BMA biomass.

The entrapment of DSi within the sediments by benthic diatoms may also explain the positive correlation between BMA biomass and pore water DSi concentration. Microalgal mats were visibly detected on the Masonboro Sound sandflat throughout most of the study period. BMA have been found to form mats which could reduce physical disturbances and slow nutrient diffusion rates out of the sediments (Kelderman et al. 1988, Sundbäck \& Jonsson 1988, Decho 1990). This finding is supported by the observation that BMA were able to decrease water column DSi concentrations to below 4 pMM from November to March cven though pore water concentrations were above $30 \mu \mathrm{M}$ for most of this period. Even with high pore water concentrations, BMA can not only influence pore water nutrient efflux, but lab and field results indicate an obvious ability, and possible preference, for the uptake of water column DSi.

The observation that benthic diatoms are very abundant and need a lot of silica per unit of chlorophyll, when compared to phytoplankton, indicates that benthic diatoms could be a dominant regulator of the DSi 
cycle in shallow-water habitats. BMA control DSi flux across the sediment-water interface by direct uptake from the water column and by cohesive mat formation on the sediment surface (Ullman \& Sandstrom 1987, Decho 1990, Sundbäck et al 1991, Marinelli 1992) BMA control of DSi cycles is even more significant when considering the possible effects on overall system productivity. The observation that phytoplankton are silica-limited at least part of the year indicates that BMA control of DSi fluxes could also result in a growth advantage for non-silica-containing phytoplankton. When nitrogen and phosphorus are increased relative to $\mathrm{DSi}$, diatoms are placed at a competitive disadvantage with other microalgae, resulting in a possible shift in species composition and lower overall community production (Officer \& Ryther 1980, Nilsson et al. 1991). These results suggest that BMA not only contribute to but may also affect the amount and type of phytoplankton primary production in soft-bottom estuarine communities.

Acknowledgements. This research was supported by the UNC Sea Grant College Program, the Northeast New Hanover Conservancy, New Hanover County, and the Center for Marine Science Research at UNC-Wilmington. This is CMSR contribution no. 168. Thanks also to Crystal Tilton and Janice Nearhof for their help, and to CMSR for covering publication costs.

\section{LITERATURE CITED}

Aller RC, Benninger LK (1981) Spatial and temporal patterns of dissolved ammonium, manganese, and silica fluxes from bottom sediments of Long Island Sound, USA. J Mar Res 39:295-314

Blackburn TH, Henriksen K (1983) Nitrogen cycling in different types of sediments from Danish waters. Limnol Oceanogr 28:477-493

Brzezinski MA (1985) The Si:C:N ratio of marine diatoms interspecific variability and the effect of some environmental variables. J Phycol 21:347-357

Busby WF, Lewin J (1967) Silicate uptake and silica shell formation by synchronously dividing cells of the diatom Navicula pelliculosa Hilse. J Phycol 3:127-131

Cahoon LB, Cooke JE (1992) Benthic microalgal production in Onslow Bay, North Carolina, USA. Mar Ecol Prog Ser 84 : 185-196

Callender E, Hammond DE (1982) Nutrient exchange across the sediment-water interface in the Potomac River estuary. Estuar Coast Shelf Sci 15:395-413

Conley DJ, Malone JC (1992) Annual cycle of dissolved silicate in Chesapeake Bay: implications for the production and fate of phytoplankton biomass. Mar Ecol Prog Ser 81:121-128

Darley WM, Ohman CT, Wimpee BB (1979) Utilization of dissolved organic carbon by natural populations of epibenthic salt marsh diatoms. J Phycol 15:1-15

Davis CO (1976) Continuous culture of marine diatoms under silicate limitation. J Phycol 12:291-300

Decho AW (1990) Microbial exopolymer secretions in ocean environments: their role in food webs and marine processes Oceanogr Mar Biol Annu Rev 28:73-153
DeMaster DJ (1981) The supply and accumulation of silica in the marine environment. Geochem Cosmochim Acta 45: $1715-1732$

Doering PH, Oviatt CA, Beatty LL, Banzon VF, Rice R, Kelly S $P$, Sullivan BK, Frithsen JB (1989) Structure and function in a model coastal ecosystem: silicon, the benthos, and eutrophication. Mar Ecol Prog Ser 52:287-299

Flint RW, Kamykowski D (1984) Benthic nutrient regeneration in south Texas coastal waters. Estuar Coast Shelf Sci 18: $221-230$

Guillard RRL, Ryther JH (1962) Studies of marine planktonic diatoms I: Cyclotella nana Hustedt and Detonula confervacea (Cleve) Gran ('f' medium). Can J Microbiol 8:229-239

Harrison PJ, Conway HL, Holmes RW, Davis CO (1977) Marine diatoms grown in chemostats under silicate or ammonium limitation. III. Cellular and chemical composition and morphology of Chaetoceros debilis, Skeletonema costatum, and Thalassiosira gravida. Mar Biol 43:19-31

Hopkinson CS, Wetzel RL (1982) In situ measurements of nutrient and oxygen fluxes in a coastal marine benthic community. Mar Ecol Prog Ser 10:29-35

Iler RK (1979) The chemistry of silica. Solubility, polymerization, colloid, surface properties, and biogeochemistry. Wiley, Chichester

Ingram RL (1971) Sieve analysis. In: Carver RE (ed) Procedures of sedimentary petrology. Wiley, Chichester, p 49-67

Kelderman P, Lindeboom. HJ, Klein J (1988) Effects of nutrient enrichment on microalgal community composition in a coastal shallow-water sediment system: an experimental study. Bot Mar 34:341-358

Krom MD (1991) Importance of benthic productivity in controlling the flux of dissolved inorganic nitrogen through the sediment-water interface in a hypertrophic marine ecosystem. Mar Ecol Prog Ser 78:163-172

Lukatelich RJ, McComb AJ (1986) Distribution and abundance of benthic microalgae in a shallow southwestern Australian estuarine system. Mar Ecol Prog Ser 27: $287-297$

Marinelli RL (1992) Effects of polychaetes on silicate dynamics and fluxes in sediments: importance of species, animal activity, and polychaete effects on benthic diatoms. J Mar Res 50:745-779

Nilsson P, Jonson B, Swanberg IL, Sundbäck K (1991) Response of a marine shallow-water sediment system to an increased load of inorganic nutrients. Mar Ecol Prog Ser 71:275-290

Officer CB, Ryther JH (1980) The possible importance of silicon in marine eutrophication. Mar Ecol Prog Ser 3:83-91

Parsons TR, Maita Y, Lalli CM (1984) A manual of chemical and biological methods for seawater analysis. Permagon Press, New York, p 25-28

Ragueneau O, De Blas Varela E, Treguer P, Queguiner B, Del Amo Y (1994) Phytoplankton dynamics in relation to the biogeochemical cycle of silicon in a coastal ecosystem of western Europe. Mar Ecol Prog Ser 106:157-172

Sundbäck K, Enoksson V, Granéli W, Petterson K (1991) Influence of sublittoral microphytobenthos on the oxygen and nutrient fluxes between sediment and water: a laboratory continuous flow study. Mar Ecol Prog Ser 74:263-279

Sundbäck K, Granéli W (1988) Influence of microphytobenthos on nutrient flux between sediment and water: a laboratory study. Mar Ecol Prog Ser 43:63-69

Sundbäck K, Jonsson B (1988) Microphytobenthic productivity and biomass in sublittoral sediments of a stratified bay, southeastern Kattegat. J Exp Mar Biol Ecol 122:63-81

Sundbäck K, Snoeijis P (1991) Effects of nutrient enrichment on microalgal community composition in a coastal shal- 
low-water sediment system: an experimental study. Bot Mar 34:341-358

UIlman WJ, Sandstrom MW (1987) Dissolved nutrient fluxes from the nearshore sediments of Bowling Green Bay, Central Great Barrier Reef Lagoon. Estuar Coast Shelf Sci 24: 289-303

Vandevivere P, Welch SA, Ullman WJ, Kirchman DL (1994) Enhanced dissolution of silicate minerals by bacteria at a near-neutral pH. Microb Ecol 27:241-251

Responsible Subject Editor: Pat Glibert, Cambridge, Maryland, USA
Welschmeyer NA (1994) Fluorometric analysis of chlorophyll $a$ in the presence of chlorophyll $b$ and phaeopigments. Limnol Oceanogr 39:1985-1992

Whitney DE, Darley WM (1979) A method for the determination of chlorophyll $a$ in samples containing degradation products. Limnol Oceanogr 24:183-187

Zeitzschel B (1979) Sediment-water interactions in nutrient dynamics. In: Tenore KR, Coull BC (ed) Marine benthic dynamics. Univ S Carolina, Georgetown, SC, p 195-218

Manuscript received: September 24, 1996

Revised version accepted: April 15, 1997 